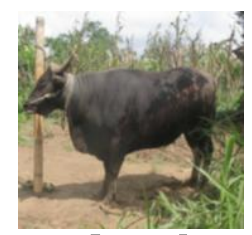

Jurnal FADET UNUD

Editor-Reviewer Article;: Dsk. P.M.A. Candrawati ę Ni Putu Mariani

\title{
PERSENTASE ORGAN DALAM BABI BALI YANG DIBERIKAN PAKAN DASAR JAGUNG-POLLARD DENGAN SUPLEMENTASI ASAM-ASAM AMINO ESENSIAL
}

\author{
Budiadnyana, I G., A. A. P. P. Wibawa, dan I. K. Sumadi \\ PS. Peternakan, Fakultas Peternakan, Universitas Udayana, Jl. P.B. Sudirman, Denpasar \\ E-mail: gedebudiadnyana@student.unud.ac.id, Telepon: +6285238645568
}

\begin{abstract}
ABSTRAK
Penelitian ini bertujuan untuk mengetahui pengaruh suplementasi asam-asam amino esensial pada pakan dasar jagung-pollard terhadap persentase bobot organ dalam babi bali jantan. Penelitian ini dilaksanakan di Jalan Sindureja, Banjar Batu Paras, Desa Padangsambian Kaja, Denpasar Barat selama 12 Minggu. Babi yang digunakan adalah babi bali jantan sebanyak 9 ekor dengan rata-rata berat badan awal 11,41 $\pm 0,91 \mathrm{~kg}$. Rancangan yang digunakan adalah Rancangan Acak Lengkap (RAL) dengan 3 perlakuan dan 3 kali ulangan. Perlakuan tersebut adalah babi bali jantan yang diberikan ransum jagung kuning $50 \%$, pollard $49 \%, \mathrm{NaCl} 0,5 \%$ dan campuran mineral $0,5 \%$ (P0), babi bali jantan yang diberikan ransum $\mathrm{P0}+$ suplementasi asam-asam amino lisin $0,75 \%$, metionin $0,20 \%$ dan triptofan $0,07 \%$ (P1), dan babi babi jantan yang diberikan ransum rekomendasi dengan $\mathrm{ME} / \mathrm{CP}$ ratio $=2800 \mathrm{kkal} / \mathrm{kg} / 16 \%(\mathrm{P} 2)$. Variabel yang diamati adalah persentase bobot jantung, bobot paru-paru, bobot hati, bobot ginjal, bobot pankreas, bobot lambung, bobot usus halus, dan bobot usus besar. Hasil penelitian ini menunjukan bahwa perlakuan (P1) nyata $(\mathrm{P}<0,05)$ mampu menurunkan persentase bobot jantung, paru-paru, hati, ginjal, pankreas, lambung, usus halus, dan usus besar. Berdasarkan hasil penelitian dapat disimpulkan bahwa suplementasi asam-asam amino esensial lisin, metionin, dan triptofan dalam pakan dasar jagung-pollard mampu menurunkan persentase bobot jantung, paru-paru, hati, ginjal, pankreas, lambung, usus halus dan usus besar.
\end{abstract}

Kata Kunci: babi bali, suplementasi, asam amino, organ dalam

\section{PERSENTAGE OF INTERNAL ORGANS IN BALI PIGS FED POLLARD-CORN BASE FEED WITH ESENTIAL AMINO ACID SUPLEMENTATION}

\begin{abstract}
This research aims to determine the effect of essential amino acid supplementation on pollard-corn base feed on internal organs weight percentages of bali boar. This research was conducted at Sindureja street, Banjar Batu Paras, Padangsambian Kaja Village, West Denpasar for 12 weeks. The boar used are 9 bali boar with an initial average weight of 11.41 $\pm 0.91 \mathrm{~kg}$. The design was used is Completely Randomized Design (CRD) with 3 treatments and 3 replications. The treatments were bali boar given rations yellow corn 50\%, pollard $49 \%, \mathrm{NaCl} 0.5 \%$, and mineral mixture $0.5 \%(\mathrm{P} 0)$, bali boar given rations $\mathrm{P} 0+$ amino acid supplementation lysine $0.75 \%$, methionine $0.20 \%$ and tryptophan $0.07 \%$ (P1), and bali boar given rations recommendation with $\mathrm{ME} / \mathrm{CP}$ ratio $2800 \mathrm{kcal} / \mathrm{kg} / 16 \%$ (P2). The variables
\end{abstract}


observed were percentage of heart weight, lung weight, liver weight, kidney weight, pancreatic weight, gastric weight, small intestine weights, and large intestine weight. The results showed that the $(\mathrm{P} 1)$ treatments significantly $(\mathrm{P}<0.05)$ be able to decrease the percentage of heart weight, lung, liver, kidney, pancreatic, stomach, small intestine, and large intestine. Based on the results of this study concluded that supplementation of a essential amino acids lysine, methionine and tryptophan in corn-pollard based feeds be able to decrease the percentage of heart weight, lung, liver, kidney, pancreatic, stomach, small intestine and large intestine.

Keywords: bali boar, supplementation, amino acid, internal organ

\section{PENDAHULUAN}

Babi bali merupakan plasma nutfah "prolifik" yang artinya mampu menghasilkan anak banyak dalam satu kali kelahiran. Peternakan babi di Bali memegang peranan penting khususnya dalam hubungannya dengan kebiasaan dan adat istiadat masyarakat Bali (Masudana, 1975). Budaarsa (2012) menyatakan bahwa salah satu adat istiadat masyarakat di Bali yaitu menggunakan babi sebagai babi guling. Kelebihan babi bali adalah tahan menderita, lebih hemat terhadap air, masih mampu bertahan hidup walau diberi makan seadanya, dan sangat cocok dipelihara di daerah yang kering. Kekurangan babi bali adalah pertumbuhannya lebih lambat dibandingkan dengan babi ras impor (Budaarsa et al. 2016).

Babi bali sekarang sulit untuk didapatkan, hal ini disebabkan pertumbuhan babi bali yang dikalahkan oleh babi ras. Soewandi dan Talib (2015) menyatakan bahwa pertambahan berat badan harian $(\mathrm{PBBH})$ babi bali adalah $0,14 \pm 0,5 \mathrm{~kg}$, sedangkan $\mathrm{PBBH}$ pada babi landrace dapat mencapai 0,24 $\pm 0,9 \mathrm{~kg}$. Puger dan Budaarsa (2014) menambahkan bahwa untuk mencapai berat badan $80 \mathrm{~kg}$ babi bali memerlukan waktu 12 bulan, sedangkan babi ras impor hanya 5-6 bulan. Sudiastra dan Budaarsa (2015) menyatakan bahwa pakan utama yang diberikan babi bali yaitu dedak padi atau pollard dan batang pisang. Keberhasilan beternak babi sangat dipengaruhi oleh kandungan nutrien ransum yang diberikan kepada ternak.

Barnes et al. (1995) menyatakan bahwa kualitas protein dalam bahan pakan dinyatakan tinggi atau rendah bergantung pada kandungan asam amino esensial dalam bahan pakan tersebut. Akan tetapi, asam-asam amino esensial yang kandunganya terbatas pada bahan pakan nabati adalah asam amino lisin, metionin dan triptofan (U.S.Pork Center of Excellence, 2010). Jagung merupakan butiran dasar dalam penyusunan formulasi pakan sekaligus merupakan sumber energi utama ternak babi, tetapi jagung sangat kekurangan asam amino lisin, metionin dan triptofan (Sumadi, 2018). Pollard adalah hasil sisa penggilingan dari 
gandum yang dapat digunakan sebagai pakan ternak, kaya protein, lemak, zat-zat mineral dan vitamin-vitamin dibandingkan dengan biji-bijian lainnya (Maynard dan Loosli, 1973).

Maka dari itu, untuk meningkatkan kualitas ransum dan menutupi kekurangan protein dalam ransum yaitu dengan suplementasi asam amino esensia lisin, metionin, dan triptofan. Budaarsa (2012) menyatakan bahwa lisin dan metionin merupakan asam amino esensial yang sangat diperlukan oleh tubuh untuk pertumbuhan. Gunawa (2018) dalam penelitiannya menyatakan bahwa suplementasi campuran lisin, metionin, dan kolin dalam ransum babi bali jantan dengan level 0,5\% dan 1\% mampu mempengaruhi dengan menurunkan persentase bobot paru-paru, hati, pankreas, lambung, dan usus halus.

\section{MATERI DAN METODE}

\section{Ternak babi}

Babi yang digunakan dalam penelitian ini adalah babi bali jantan lepas sapih sebanyak 9 ekor dengan berat badan rata-rata $11,41 \pm 0,91 \mathrm{~kg}$. Babi bali jantan dibeli dari pengepul babi bali yang ada di Desa Gerokgak, Kabupaten Buleleng, Bali.

\section{Kandang dan perlengkapan}

Kandang yang digunakan dalam penilitian adalah kandang individu yang terbuat dari kayu dan bambu dengan atap terpal. Kandang berjumlah 9 unit dengan ukuran $1 \mathrm{~m}^{2}$ per unit. Di dalam kandang terdapat tempat pakan dan minum yang terbuat dari kayu dan plastik.

\section{Alat penelitian}

Alat yang digunakan dalam penelitian ini adalah timbangan digital dengan kapasitas $10 \mathrm{~kg}$ dengan tingkat kepekaan $0,2 \mathrm{mg}$ yang digunakan untuk menimbang berat organ dalam ternak babi. Timbangan kapasitas 50kg dengan tingkat kepekaan $0,1 \mathrm{~kg}$ digunakan untuk menimbang berat badan babi dan bahan-bahan penyusun ransum.

\section{Ransum penelitian}

Ransum yang digunakan dalam penelitian ini yaitu campuran jagung kuning, pollard, konsentrat $\mathrm{CP}$ 152, $\mathrm{NaCl}$, dan mineral 10 yang diberikan tambahan lisin, metionin, dan triptofan. Komposisi bahan penyusun ransum penelitian dapat dilihat pada (Tabel 1) dan kandungan nutrien ransum penelitian pada (Tabel 2). 
Tabel 1. Komposisi Bahan Penyusun Ransum Penelitian

\begin{tabular}{|c|c|c|c|c|}
\hline \multirow{2}{*}{\multicolumn{2}{|c|}{ Komposisi Ransum (\%) }} & \multicolumn{3}{|c|}{ Perlakuan ${ }^{1)}$} \\
\hline & & P0 & P1 & $\mathbf{P 2}$ \\
\hline \multicolumn{2}{|l|}{ Jagung kuning } & 50 & 50 & 40 \\
\hline \multicolumn{2}{|l|}{ Pollard } & 49 & 49 & 43 \\
\hline \multicolumn{2}{|l|}{ Konsentrat CP 152} & - & - & 16 \\
\hline \multicolumn{2}{|l|}{ Mineral 10} & 0,5 & 0,5 & 0,5 \\
\hline \multicolumn{2}{|l|}{$\mathrm{NaCl}$} & 0,5 & 0,5 & 0,5 \\
\hline \multicolumn{2}{|l|}{ TOTAL } & 100 & 100 & 100 \\
\hline \multicolumn{5}{|c|}{ Suplementasi asam-asam amino esensial } \\
\hline \multicolumn{2}{|c|}{ Lisin } & - & 0,75 & - \\
\hline \multicolumn{2}{|l|}{ Metionin } & - & 0,20 & - \\
\hline \multicolumn{2}{|l|}{ Triptofan } & - & 0,07 & - \\
\hline \multicolumn{5}{|c|}{$\begin{array}{l}\text { Keterangan: } \\
\text { 1) Perlakuan P0 : Babi bali jantan yang diberikan ransum jagung kuning } 50 \% \text {, pollard } 49 \%, \mathrm{NaCl} 0,5 \% \text { dan } \\
\text { campuran mineral } 0,5 \% \text {. }\end{array}$} \\
\hline \multirow{2}{*}{\multicolumn{5}{|c|}{$\begin{aligned} \text { Perlakuan P1 : Babi bali jantan yang diberikan ransum P0 + suplementasi asam-asam amino lisin } 0,75 \% \text {, } \\
\text { metionin 0,20\% dan triptofan } 0,07 \% \\
\text { Perlakuan P2: Babi bali jantan yang diberikan ransum rekomendasi Sumadi et al. (2016) }\end{aligned}$}} \\
\hline & & & & \\
\hline \multicolumn{5}{|c|}{ Tabel 2. Kandungan Nutrien Ransum Penelitian } \\
\hline \multirow{2}{*}{ Kandungan Nutrien (\%) } & \multicolumn{3}{|c|}{ Perlakuan } & \multirow{2}{*}{ Standar ${ }^{2}$} \\
\hline & P0 & P1 & $\mathbf{P 2}^{1)}$ & \\
\hline $\mathrm{ME}(\mathrm{Kkal} / \mathrm{kg})$ & 2825 & 2825 & 2794,25 & 2800 \\
\hline Protein kasar & 11,84 & 11,84 & 16,15 & 16 \\
\hline Lisin & 0,42 & 1,17 & - & 1,15 \\
\hline Metionin & 0,46 & 0,66 & - & 0,65 \\
\hline Triptofan & 0,14 & 0,21 & - & 0,21 \\
\hline
\end{tabular}

Keterangan :

1) Berdasarkan rekomendasi Sumadi et al. (2016)

2) Berdasarkan standar NRC (2012)

\section{Tempat dan waktu}

Penelitian ini dilaksanakan di Jalan Sindureja, Dusun Batu Paras, Desa Padangsambian Kaja, Denpasar Barat, Bali. Penelitian ini dilaksanakan selama 12 minggu (3 bulan).

\section{Rancangan penelitian}

Penelitian ini menggunakan Rancangan Acak Lengkap (RAL) yang terdiri atas 3 perlakuan dan 3 ulangan. Ketiga perlakuan yang dicobakan kepada babi bali jantan lepas sapih terdiri atas:

P0 : Babi bali jantan yang diberikan ransum jagung kuning $50 \%$, pollard $49 \%, \mathrm{NaCl}$ $0,5 \%$ dan campuran mineral $0,5 \%$.

P1 : Babi bali jantan yang diberikan ransum P0 + suplementasi asam-asam amino lisin $0,75 \%$, metionin $0,20 \%$ dan triptofan $0,07 \%$

P2 : Babi bali jantan yang diberikan ransum rekomendasi Sumadi et al. (2016) 


\section{Pengacakan}

Babi bali jantan lepas sapih sebanyak 9 ekor ditimbang kemudian diberikan nomor dan dicari berat rata-rata yang tidak jauh berbeda. Selanjutnya babi ditempatkan pada kandang secara berurutan sesuai dengan perlakuan.

\section{Pencampuran ransum}

Pencampuran ransum dilakukan dengan menimbang bahan-bahan penyusun ransum, kemudian pencampuran ransum dimulai dengan bahan yang jumlahnya paling banyak dan menumpuknya sampai dengan bahan yang jumlahnya paling sedikit. Cara pencampurannya dengan menaburkan bahan-bahan secara melingkar di atas plastik. Setelah tercampur secara merata, ransum ditimbang kemudian disimpan untuk ransum penelitian.

\section{Cara pemberian ransum dan air minum}

Ransum yang diberikan berbentuk tepung "mash" dengan komposisi ransum yaitu: jagung kuning, pollard, konsentrat $\mathrm{CP} 152, \mathrm{NaCl}$, mineral 10, tambahan lisin, metionin, dan triptofan. Pemberian ransum dilakukan sebanyak dua kali dalam sehari, pagi pukul 07.30 wita dan sore pukul 16.30 wita. Pemberian air minum dilakukan secara ad libitum.

\section{Variabel yang diamati}

Variabel yang diamati dalam penelitian ini, meliputi: persentase bobot jantung, bobot paru-paru, bobot hati, bobot ginjal, bobot pankreas, bobot lambung, bobot usus halus dan bobot usus besar. Penimbangan organ dalam hanya dilakukan sekali dalam penelitian ini, yaitu diakhir penelitian. Organ dalam yang diamati segera diambil dan dipisahkan dari jaringan-jaringan yang melekat seperti lemak dan kotoran, setelah bersih ditimbang bobotnya. Data yang diolah, yaitu bobot organ dalam per bobot potong ternak babi.

Persentase Bobot Organ Dalam $=\frac{\text { Bobot Organ Dalam (gram) }}{\text { Bobot Potong Babi (gram) }} \times 100 \%$

\section{Analisis statistika}

Semua data yang diperoleh dari penelitian ini, dianalisis dengan sidik ragam. Apabila terdapat hasil yang berbeda nyata $(\mathrm{P}<0,05)$ maka dilanjutkan dengan uji jarak berganda Duncan pada taraf 5\% (Steel dan Torrie, 1991). 


\section{HASIL DAN PEMBAHASAN}

\section{Persentase bobot jantung}

Hasil penelitian menunjukan bahwa persentase bobot jantung perlakuan P1 adalah 0,53\% (Tabel 3). Persentase bobot jantung yang diberikan perlakuan P0 secara nyata lebih besar 24,53\% dan P2 secara nyata lebih kecil 13,21\% dengan perlakuan P1. Semua perlakuan tersebut secara statistik berbeda nyata $(\mathrm{P}<0,05)$. Pemberian suplementasi asam-asam amino esensial lisin, metionin, dan triptofan $(\mathrm{P} 1)$ secara nyata $(\mathrm{P}<0,05)$ mampu menurunkan persentase bobot jantung babi bali jantan.

Tabel 3. Persentase Organ Dalam Babi Bali yang Diberikan Pakan Dasar Jagung-Pollard dengan Suplementasi Asam-Asam Amino Esensial

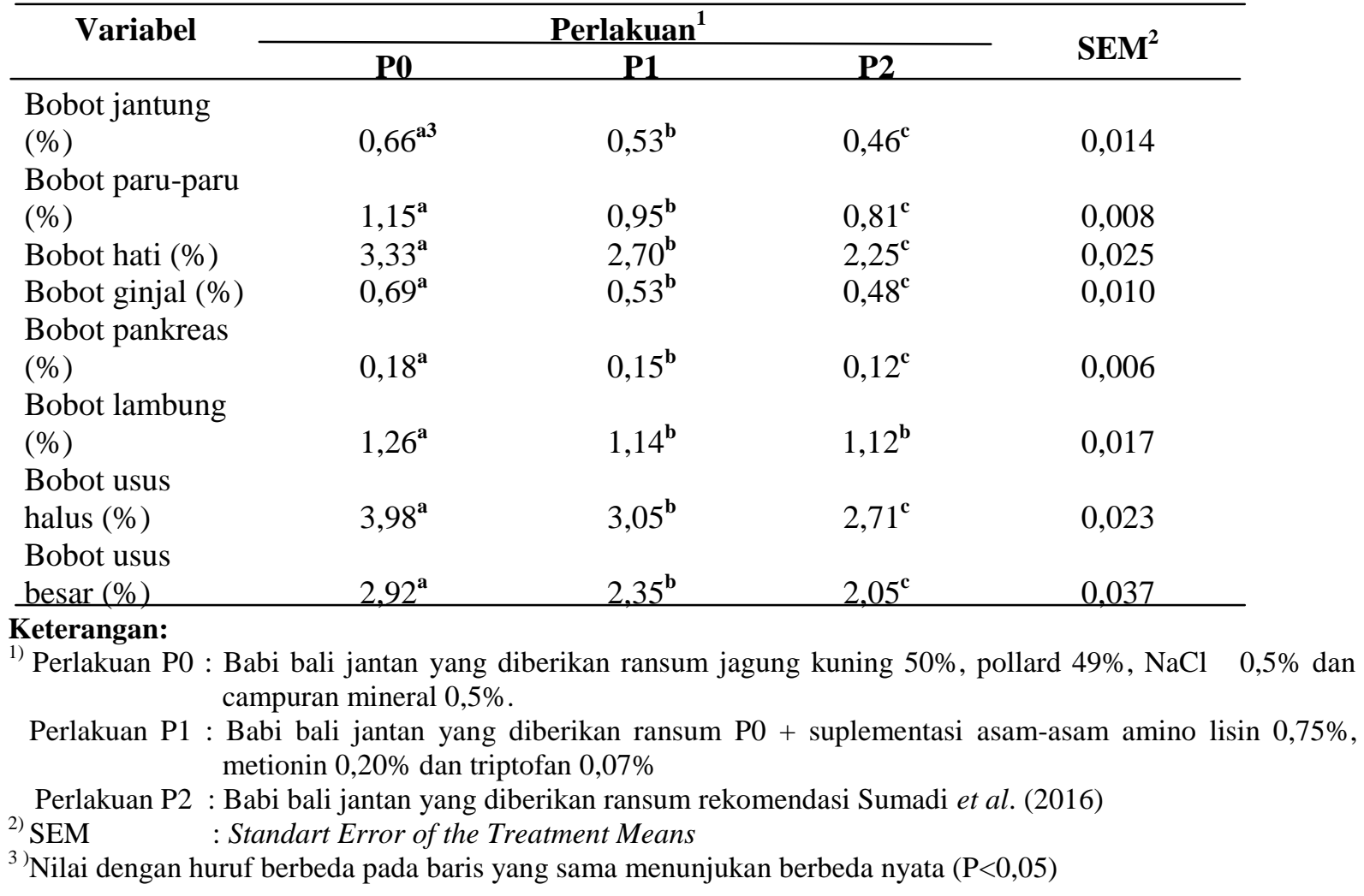

\section{Persentase bobot jantung}


Hasil penelitian menunjukan bahwa persentase bobot jantung perlakuan P1 adalah 0,53\% (Tabel 3). Persentase bobot jantung yang diberikan perlakuan P0 secara nyata lebih besar 24,53\% dan P2 secara nyata lebih kecil 13,21\% dengan perlakuan P1. Semua perlakuan tersebut secara statistik berbeda nyata $(\mathrm{P}<0,05)$. Pemberian suplementasi asam-asam amino esensial lisin, metionin, dan triptofan $(\mathrm{P} 1)$ secara nyata $(\mathrm{P}<0,05)$ mampu menurunkan persentase bobot jantung babi bali jantan.

Gunawa (2018) dalam penelitiannya suplementasi campuran lisin, metionin, dan kolin dalam ransum dengan level 1\% didapatkan persentase bobot jantung babi bali jantan sebesar 0,52\% dari bobot tubuhnya. Penurunan persentase bobot jantung dikarenakan kualitas pakan yang diberikan baik sehingga memperingan kerja jantung dalam mengedarkan zat-zat makanan ke seluruh tubuh. Hal ini didukung oleh pernyataan Forrest et al. (1975) bahwa komponen dari organ dalam dipengaruhi oleh pakan, bangsa, jenis kelamin, dan berat potong. Jantung merupakan pompa berotot yang menjamin aliran darah pada dua sistem sirkulasi yaitu, sirkulasi pulmoner untuk mengambil oksigen dari udara dan membuang karbondioksida melalui paru-paru dan sirkulasi sistemik untuk mengedarkan zat-zat makanan, oksigen, hormon ke jaringan tubuh dan sekaligus mengangkat ampas atau sisa metabolisme (Hartono, 1976).

\section{Persentase bobot paru-paru}

Hasil penelitian menunjukkan bahwa persentase bobot paru-paru yang diberikan perlakuan P1 adalah 0,95\% (Tabel 3). Persentase bobot paru-paru ternak yang diberikan perlakuan P0 secara nyata lebih besar 21,05\% dan P2 secara nyata lebih kecil 14,74\% dengan perlakuan P1. Semua perlakuan tersebut secara statistik berbeda nyata $(\mathrm{P}<0,05)$. Pemberian suplementasi asam-asam amino esensial lisin, metionin, dan triptofan (P1) secara nyata $(\mathrm{P}<0,05)$ mampu menurunkan persentase bobot paru-paru babi bali jantan. Hasil penelitian ini lebih besar dibandingkan penelitian Gunawa (2018) dimana suplementasi campuran lisin, metionin, dan kolin dalam ransum dengan level $1 \%$ didapatkan persentase bobot paru-paru babi bali jantan sebesar $0,77 \%$ dari bobot tubuhnya.

Penurunan persentase bobot paru-paru dikarenakan suplementasi asam amino esensial lisin, metionin, dan triptofan dalam pakan dasar jagung-pollard mampu mencegah organ dalam untuk bekerja lebih ekstra dalam proses metabolisme dalam tubuh. Soeharsono (2010) menyatakan bahwa paru-paru merupakan organ pada sistem pernapasan yang berhubungan dengan sistem peredaran darah. Paru-paru berfungsi untuk menukar oksigen dari udara dengan karbondioksida dari darah. Bobot badan ternak juga dapat mempengaruhi persentase 
organ dalam. Hal ini sejalan dengan hasil penelitian Aritonang (2007) bahwa semakin bertambahnya umur maka diikuti oleh meningkatnya berat hidup, namun menurunkan persentase edible offal yang dihasilkan dengan membandingkan berat edible offal dengan berat hidup babi nias jantan.

\section{Persentase bobot hati}

Hasil penelitian menunjukkan bahwa persentase bobot hati yang diberikan perlakuan P1 adalah 2,70\% (Tabel 3). Persentase bobot hati ternak yang diberikan perlakuan P0 secara nyata lebih besar 23,33\% dan P2 secara nyata lebih kecil 16,67\% dengan perlakuan P1. Semua perlakuan tersebut secara statistik berbeda nyata $(\mathrm{P}<0,05)$. Pemberian suplementasi asam-asam amino esensial lisin, metionin, dan triptofan $(\mathrm{P} 1)$ secara nyata $(\mathrm{P}<0,05)$ mampu menurunkan persentase bobot hati babi bali jantan. Hasil penelitian P2 lebih kecil dibandingkan dengan hasil penelitian Gunawa (2018) bahwa suplementasi campuran lisin, metionin, dan kolin dalam ransum dengan level $1 \%$ didapatkan persentase bobot hati babi bali jantan sebesar 2,26\% dari bobot tubuhnya.

Penurunan persentase bobot hati dikarenakan pemberian pakan dengan kualitas baik sehingga memperingan kerja hati sebagai penyaring zat-zat berbahaya pada pakan. Hal tersebut sejalan dengan pendapat Ensminger (1992) yang menyatakan bahwa salah satu fungsi hati adalah sebagai detoksifikasi komponen berbahaya yang terdapat dalam pakan. Nickel et al. (1997) menyatakan bahwa hati mempunyai peranan dalam menyaring zat-zat makanan yang sudah tercena sebelum masuk kedalam sirkulasi darah, menyimpan glikogen dan mengubah sisa pembakaran protein menjadi asam urat, sebagai penetralisir racun, serta sebagai penyedia energi untuk kebutuhan ternak berdasarkan ketersediaan glikogen.

\section{Persentase bobot ginjal}

Hasil penelitian menunjukkan bahwa persentase bobot ginjal yang diberikan perlakuan P1 adalah 0,53\% (Tabel 3). Persentase bobot ginjal ternak yang diberikan perlakuan P0 secara nyata lebih besar 30,19\% dan P2 secara nyata lebih kecil 9,43\% dengan perlakuan P1. Semua perlakuan tersebut secara statistik berbeda nyata $(\mathrm{P}<0,05)$. Pemberian suplementasi asamasam amino esensial lisin, metionin, dan triptofan $(\mathrm{P} 1)$ secara nyata $(\mathrm{P}<0,05)$ mampu menurunkan persentase bobot ginjal babi bali jantan. Hasil penelitian ini lebih besar dibandingkan dengan Pond dan Manner (1974) yang menyatakan bahwa persentase ginjal pada babi berat $36,1 \mathrm{~kg}$ adalah $0,47 \%$ dari bobot tubuhnya. Hardiawan et al. (2015) dalam penelitiannya babi bali yang mendapatkan ransum ditambah ekstrak kunyit (Curcuminoid) 
$0,06 \mathrm{ml} / 1 \mathrm{~kg}$ berat badan didapatkan persentase bobot ginjal sebesar $0,47 \%$ dari bobot badannya.

Penurunan persentase bobot ginjal dalam penelitian ini dikarenakan pemberian pakan dengan kualitas baik dapat meningkatkan bobot badan ternak yang menyebabkan persentase ginjal menurun. Hal ini sejalan dengan hasil penelitian Aritonang (2007) bahwa semakin bertambahnya umur maka diikuti oleh meningkatnya berat hidup, namun menurunkan persentase edible offal yang dihasilkan dengan membandingkan berat edible offal dengan berat hidup babi nias jantan. Ginjal merupakan alat tubuh vital yang memiliki banyak fungsi yaitu, membuang ampas metabolisme dengan cara menyaring darah berupa air seni, mengatur kadar air, elektrolit dan bahan-bahan lain dari darah, membuang bahan-bahan yang berlebihan ataupun yang tidak diperlukan bagi tubuh dan mengatur tekanan darah.

\section{Persentase bobot pankreas}

Hasil penelitian menunjukkan bahwa persentase bobot pankreas yang diberikan perlakuan P1 adalah 0,15\% (Tabel 3). Persentase bobot pankreas ternak yang diberikan perlakuan P0 secara nyata lebih besar 20,00\% dan P2 secara nyata lebih kecil 20,00\% dengan perlakuan P1. Semua perlakuan tersebut secara statistik berbeda nyata $(\mathrm{P}<0,05)$. Pemberian suplementasi asam-asam amino esensial lisin, metionin, dan triptofan (P1) secara nyata $(\mathrm{P}<0,05)$ mampu menurunkan persentase bobot pankreas babi bali jantan. Hasil penelitian ini lebih kecil dibandingkan penelitian Gunawa (2018) bahwa suplementasi lisin, metionin, dan kolin dalam ransum dengan level 1\% didapatkan persentase bobot pankreas babi bali sebesar $0,23 \%$ dari bobot tubuhnya.

Penurunan persentase bobot pankreas dikarenakan pemberian pakan dengan kualitas baik memperingan kerja pankreas untuk memecah protein dan polipeptida menjadi peptide dan memecah peptida-peptida menjadi asam-asam amino, sehingga dapat dimanfaatkan oleh tubuh ternak. Sejalan dengan pendapat Sumadi (2018), yang menyatakan bahwa pankreas berfungsi sebagai organ yang paling vital dalam proses pencernaan untuk memproduksi dan mensekresikan enzim yang dibutuhkan untuk pencernaan chyme dan pencegahan kerusakan sel-sel usus halus akibat $\mathrm{pH}$ rendah. Enzim-enzim yang berasal dari pankreas adalah lipase, tripsin, kimotripsin dan amilase. Lipase berfungsi untuk menghidrolisis lemak menjadi asamasam lemak dan gliserida; tripsin berfungsi memecah protein dan polipeptida menjadi peptide; kimotripsin berfungsi memecah peptida-peptida menjadi asam-asam amino; dan amilase memecah pati menjadi disakarida dan disakarida dipecah lagi menjadi monosakarida. 


\section{Persentase bobot lambung}

Hasil penelitian menunjukkan bahwa persentase bobot lambung yang diberikan perlakuan P1 adalah 1,14\% (Tabel 3). Persentase bobot lambung ternak yang diberikan perlakuan P0 secara nyata lebih besar 10,53\% dan P2 tidak berbeda nyata lebih kecil 1,75\% dengan perlakuan P1. Perlakuan P2 secara statistik menunjukan hasil berbeda tidak nyata $(\mathrm{P}>0,05)$. Pemberian suplementasi asam-asam amino esensial lisin, metionin, dan triptofan (P1) secara nyata $(\mathrm{P}<0,05)$ mampu menurunkan persentase bobot lambung babi bali jantan. Gunawa (2018) dalam penelitiannya menyatakan bahwa suplementasi campuran lisin, metionin, dan kolin dalam ransum dengan level $1 \%$ didapatkan persentase bobot lambung babi bali jantan sebesar $1,13 \%$ dari bobot badannya.

Penurunan persentase bobot lambung dikarenakan pemberian pakan dengan kualitas baik memperingan kerja lambung dalam memecah protein menjadi lebih sederhana tetapi tidak sepenuhnya memisahkan seluruh protein menjadi asam amino. Sejalan dengan pendapat Hartono (1976) lambung berfungsi sebagai tempat untuk menyimpanan makanan. Lambung babi mempunyai kelenjar yang menghasilkan getah pencernaan yang mengandung enzim, untuk pencernaan secara enzimatik. Sumadi (2018) dalam bukunya menyatakan di lambung terdapat enzim pencernaan, khususnya pepsinogen. Pepsinogen kemudian dipecah oleh asam klorida untuk membentuk pepsin, yang sangat berperan dalam pemecahan protein.

\section{Persentase bobot usus halus}

Hasil penelitian menunjukkan bahwa persentase bobot usus halus yang diberikan perlakuan P1 adalah 3,05\% (Tabel 3). Persentase bobot usus halus ternak yang diberikan perlakuan P0 secara nyata lebih besar 30,49\% dan P2 secara nyata lebih kecil 11,15\% dengan perlakuan P1. Semua perlakuan tersebut secara statistik berbeda nyata $(\mathrm{P}<0,05)$. Pemberian suplementasi asam-asam amino esensial lisin, metionin, dan triptofan (P1) secara nyata $(\mathrm{P}<0,05)$ mampu menurunkan persentase bobot usus halus babi bali jantan. Hasil penelitian perlakuan P2 lebih kecil dibandingkan penelitian Gunawa (2018) bahwa suplementasi campuran lisin, metionin, dan kolin dalam ransum dengan level $1 \%$ didapatkan persentase bobot usus halus babi bali jantan sebesar 2,90\% dari bobot tubuhnya.

Penurunan persentase usus halus dikarenakan suplementasi asam amino esensial lisin, metionin, dan triptofan dalam pakan dasar jagung-pollard memperingan kerja usus halus dalam menyerap zat-zat makanan yang megakibatkan peningkatan bobot badan ternak. Budaarsa (2012) menyatakan bahwa lisin dan metionin merupakan asam amino esensial yang sangat diperlukan oleh tubuh untuk pertumbuhan. Hal ini didukung oleh U.S. Pork Center of 
Execellence (2010) asam amino lisin dan metionin sangat penting dalam pertumbuhan babi, amun kandunganya terbatas pada bahan pakan nabati. Menurut Sundari et al. (2004) lisin dapat meningkatkan pembentuan daging yang memerlukan banyak energi, sehingga retensi energi dalam bentuk lemak menurun. Bobot usus halus dipengaruhi oleh kandungan serat kasar yang terdapat dalam ransum. Hal ini sejalan dengan pendapat Syamsuhaidi (1997) menyatakan bahwa peningkatan kadar serat kasar dalam ransum, cendrung akan memperpanjang usus. Sumadi (2018) menyatakan bahwa usus halus dibagi menjadi tiga bagian yaitu: duodenum, jejunum dan ileum yang berfungsi sebagai tempat utama penyerapan dalam nutrien.

\section{Persentase bobot usus besar}

Hasil penelitian menunjukkan bahwa persentase bobot usus besar yang diberikan perlakuan P1 adalah 2,35\% (Tabel 3). Persentase bobot usus besar ternak yang diberikan perlakuan P0 secara nyata lebih besar 24,25\% dan P2 secara nyata lebih kecil 12,77\% dengan perlakuan P1. Semua perlakuan tersebut secara statistik berbeda nyata $(\mathrm{P}<0,05)$. Pemberian suplementas asam-asam amino esensial lisin, metionin, dan triptofan (P1) secara nyata $(\mathrm{P}<0,05)$ mampu menurunkan persentase bobot usus besar babi bali jantan.

Gunawa (2018) dalam penelitiannya menyatakan bahwa suplementasi campuran lisin, metionin, dan kolin dalam ransum dengan level $1 \%$ didapatkan hasil persentase bobot usus besar babi bali jantan sebesar 2,44\% dari bobot tubuhnya. Penurunan persentase bobot usus besar dikarenakan pemberian pakan dengan kualitas baik memperingan kerja usus besar, sehingga dapat meningkatkan bobot badan ternak. Sejalan dengan pendapat Budaarsa (2012) menyatakan bahwa lisin dan metionin merupakan asam amino esensial yang sangat diperlukan oleh tubuh untuk pertumbuhan. Sihombing (2006) menyatakan bahwa usus besar terdiri atas tiga bagian yaitu kolon, sekum, dan rektum. Fungsi usus besar adalah menyerap air, menyerap vitamin dan mineral, dan menghasilkan lendir sebagai pelicin.

\section{SIMPULAN DAN SARAN}

Berdasarkan hasil penelitian ini dapat disimpulkan bahwa suplementasi asam-asam amino esensial lisin, metionin, dan triptofan dalam pakan dasar jagung-pollard dapat menurunkan persentase bobot jantung, paru-paru, hati, ginjal, pankreas, lambung, usus halus dan usus besar. Berdasarkan hasil penelitian ini dapat disarankan kepada para peternak babi, jika tidak menggunakan konsentrat dalam pakan bisa dengan suplementasi asam-asam amino esensial lisin, metionin, dan triptofan. 


\section{UCAPAN TERIMAKASIH}

Penulis mengucapkan terima kasih kepada Rektor Universitas Udayana Prof. Dr. dr. A. A. Raka Sudewi, Sp.S (K) dan Dekan Fakultas Peternakan Universitas Udayana Dr. Ir. I Nyoman Tirta Ariana, MS yang telah memberikan kesempatan dan fasilitas kepada penulis selama menjalani perkuliahan di Fakultas Peternakan, Universitas Udayana.

\section{DAFTAR FUSTAKA}

Aritonang, N. S. 2007. Persentase edible offal babi nias jantan pada berbagai umur ternak. Jurnal Peternakan Indonesia. 12(1): 60-62.

Barnes, D. M., C. C. Calvert and K. C. Klasing. 1995. Methionin deficiency decreases protein accretion and system but not rna acylation in muscles of chick. J. Nutr. 125: $2623-2630$.

Budaarsa K. 2012. Babi Guling Bali Dari Beternak, Kuliner, Hingga Sesaji. Denpasar. Buku Arti

Budaarsa, K., A.W. Puger dan I. M. Suasta. 2016. Eksplorasi komposisi pakan tradisional babi bali. Majalah Ilmiah Peternakan. 19(1):6-11.

Ensminger. M. E. 1992. Poultry Science. $3^{\text {th }}$ Edition. Interstate Publisher. Inc., Danville.

Forrest, J. C., E. D. Aberle, H. B. Herdrick, M. D. Judge and R. A. Merkel. 1975. Principles of Meat Science. W.H. Freeman and Co. San Fransisco.

Gunawa, I. D. P.W. 2018. Pengaruh Suplementasi Campuran Lisin, Metionin, Dan Kolin Dalam Ransum Terhadap Organ Dalam Babi Bali Jantan. Skripsi. Fakultas Peternakan. Universitas Udayana. Denpasar.

Hartono, 1976. Pengantar Kuliah Histologi II. Bagian Histologi Departemen Zoologi. Fakultas Kedokteran Hewan Institut Pertanian Bogor.

Hardiawan, N. D., I G. Mahardika dan I. P. A. Astawa. 2015. Pengaruh pemberian ekstrak kunyit (Curcuminoid) dalam ransum terhadap organ dalam babi bali. Peternakan Tropika. 3(3): 492-500.

Masudana, I.W. 1975. Peternakan Babi di Daerah Bali, Usaha Perbaikan Melalui Pembibitan, Dinas Peternakan Provinsi Bali. Denpasar.

Maynard L., A. and J. K. Loosli. 1973. Animal Nutrition. $6^{\text {th }}$ Edition. Tata Mc. Graw Hill Publishing Company Ltd., New Delhi.

National Research Council (N. R. C.). 2012. Nutrient Requirements of Swine. $10^{\text {th }}$ Edition. Rev. United State Dept. of Agriculture, USA. 
Nickel, R,. A. Schummer, E. Seiferle, W. G. Siller and P. A. L. Weight. 1997. Anatomy of Domestika Bird. Verlag. Paul Parey, Berlin.

Pond, W. G. dan J. H. Manner. 1974. Swine Production in Temperature and Tropical Enveronments, W. H. Freeman and Company. San Francisco.

Sihombing, D.T.H. 2006. Ilmu Ternak Babi. Gadjah Mada University Press, Yogyakarta.

Puger, A. W. dan K. Budaarsa. 2014. Eksplorasi Ragam Komposisi Pakan Tradisional Babi Bali. Laporan Penelitian. Fakultas Peternakan, Universitas Udayana. Denpasar

Soeharsono, H. 2010. Fisiologi Ternak. Widya Padjadjaran. Bandung.

Soewandi, B. D. P. dan C. Talib. 2015. Pengembangan Ternak Babi Lokal di Indonesia. Wartazoa. 25(1):039-046

Steel R.D.G dan J.H. Torrie. 1991. Prinsip dan Prosedur Statistika. Jakarta: PT. Gramedia.

Sudiastra, I. W. dan K. Budaarsa. 2015. Studi ragam eksterior dan karakteristik reproduksi babi bali. Majalah Ilmiah Peternakan. 18(3):100-105.

Sumadi,I. K., I. M. Suasta, I. P. A. Astawa dan A. W. Puger. 2016. Pengaruh ME/CP ratio ransum terhadap performans babi bali. Majalah Ilmiah Peternakan. 19(2):77-79.

Sumadi, I.K. 2018. Nutrisi Ternak Babi. Swasta Nulus. J1. Tukad Batanghari VI. B No. 9 Denpasar - Bali.

Sundari, L., C. M. Srilestari dan H. I. Wahyuni, 2004. Komposisi lemak tubuh kelinci yang mendapatkan pakan pellet dengan berbagai aras lisin. Seminar Nasional. Fakultas Peternakan. Universitas Diponogoro. Semarang.

Syamsuhaidi. 1997. Penggunaan Duckweed (Family Lemnacea) sebagai Pakan Serat Sumber Protein dalam Ransum Ayam Pedaging. Disertasi. Program Pascasarjana Institut Pertanian Bogor, Bogor.

U.S. Pork Centre for Exellent. 2010. National Swine Nutrition Guide. U.S. Pork Center of Excellence. 1776 NW 114th St. Des Moines, IA 50325. 